\title{
Current or Recent Employee or Volunteer in Nursing Home
}

National Cancer Institute

\section{Source}

National Cancer Institute. Current or Recent Employee or Volunteer in Nursing Home. NCl Thesaurus. Code C102615.

An individual who is presently or not long ago worked or offered to assist without pay at a residential health care facility for persons with chronic illness or disability. 